\title{
Counterlight: Mimesis, Potential, and Praxis in the Making of the Postmodern Subject
}

\author{
Philip Lorenz \\ Margherita Pascucci \\ New York University
}

In his introduction to the English edition of Deleuze and Guattari's Anti-Oedipus, Foucault writes that it "is the connection of desire to reality (and not its retreat into the forms of representation) that possesses revolutionary force... " (xiii-xiv). We would like to consider the possibility that what Foucault means by this connection is the labor involved in the construction of the world via the imagination.

Our argument consists of paradoxical movements. To begin with, we focus on the political aspect of the postmodern by reading a distinctly pre-modern text: Lope de Vega's Fuente Ovejuna. We argue here that in Lope's play about a collective rebellion of the multitude, one already discerns the contours of a certain 'postmodern' conception of the subject in terms of a productive and collective praxis.

Next, we take up the discussion of the postmodern at the point of crossing of philosophy and poetics, as we examine the role of mimesis in subject formation as a passage from dynamis to energeia (potentia to actuality).

Both lines of inquiry--on the concepts of multitudo and mimesis--converge, finally, at the point which marks the political crux of all aesthetics, which is the problem of agencythat is, of the subject.

In his book on Spinoza, L'Anomalía Selvaggia, Antonio Negri writes,

Politics is the metaphysics of the imagination, the metaphysics of the human constitution of reality, the world. The truth lives in the world of the imagination; it is possible to have adequate ideas that are not exhaustive reality but open to and constitutive of reality, which are intensively true; consciousness is constitutive; being is not only something found (not only a possession) but also activity, power; there is not only Nature, there is also second nature, nature of the proximate cause, constructed being. (97)

Postmodernism defines the political space as an open one in which the subject engages in a productive and constitutive struggle-in the interpretive effort involved in the construction of community. We link this project to a reading of Aristotelian mimesis as labor, which in Fuente Ovejuna is figured in terms of what we might call a "theatricalist poetics"-a making of the self that is essentially theatrical, as it operates in terms of a dramatic construction. Our use of 'essence' here reflects our attempt to propose what for sorne might seem like an

\footnotetext{
See, for example, the first line of Aristotle's Poetics re: the "potential" of poetry. Later, "The potential of tragedy exists even without a performance and actors" [50bl7].
} 
untimely recuperation of a theory of the political actor in terms of an 'essential' characteristic, by which we mean, the construction of being. Negri writes that, "[o]ntology is not a theory of foundation. It is a theory about our immersion in being and about being's continuous construction" (Labor of Dionysus, 287).

Our own understanding of the relations between essence and construction rests on the nexus of power and poetics, another name for which is "sovereignty." That sovereignty can be viewed not as an exclusively political concept but also as one related to the problem of reference has emerged in recent philosophical work. Giorgio Agamben, for example, argues that sovereignty "is the originary structure in which law refers to life and includes it in itself by suspending it." 2 For Agamben 'constituting power,' which one might translate as 'agency,' cannot be understood apart from a necessary relation to sovereignty, or 'absolute power.'

Negri takes a different position. For him, the pressing political questions for us today are precisely those which raise the possibility of the collective construction of community apart from the inevitable relation to sovereign power that Agamben describes. Negri asks, "Is it possible to conceive community outside of sovereignty as a separate and autonomous entity?. . Is a juridical and political theory possible that takes away the necessity of the one as foundation of the multitude?" (Labor of Dionysus, 308).

We introduce this debate on the relation between agency and absolute power because we see it in fact as a re-presentation of a situation already dramatized in Lope. As you may recall, after having killed their Commander, the entire village of Fuente Ovejuna is tortured by the Catholic Kings' inquisitor in order to attribute the crime to an actor. Yet no one will confess, and the frustrated Judge must report back to his sovereigns:

\author{
Trecientos he atormentado \\ con no pequeño rigor. . . \\ Hasta niños de diez años \\ al potro arrimé... . \\ o los has de perdonar, \\ o matar la villa toda. $(2373-2384)^{3}$
}

\footnotetext{
${ }^{2}$ Agamben uses Nancy's term, 'ban,' for "law's potentiality [dynamis)] to maintain itself in its own privation." One can not know if he who has been banned is outside or inside the juridical order. The "force of law is that it holds life in its ban by abandoning it" (Homo Sacer 29).

Agamben asks, "Since the ban is a form of relation, is it possible to think the political beyond relation?" (HS 29). Negri argues that constituting power (the "praxis of a constituting act") is not reducible to the principle of sovereignty. Negri's "constituting power" is the "act of choice that opens a horizon, the radical enacting of something that didn't exist before" (HS 43).

3 "I tormented three hundred (of them) / not with little harshness / I even made ten year old children ride the rack. / You must either pardon them / or kill the whole town." (My translation.)
} 
To which the King replies in the play's penultimate lines,

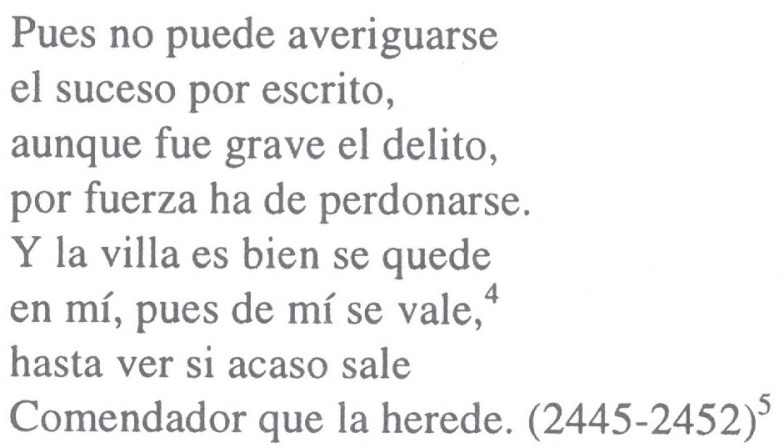

The truth of the event cannot be 'subjected' to reason here ("averiguarse"-sujetarlo (la verdad) a la razón). In its resistance to written representation, history becomes impossible to determine, and we are left with a real aporia: an undecidable occurrence which yet requires a decision in order to reinstate a juridical order. In the meantime, the political space has been cleared, as sovereign power is momentarily suspended. Into this vacuum, the villagers insert their own, founding, collective act of resistance. Thus, in a situation in which no decision is possible, it is the multitude itself that produces the meaning of the event. Another name for this collective production of meaning is 'labor,' a term which has to understood as the work involved in the production of subjectivity. Negri cites Marx's Grundrisse:

[T]he communal substance of all commodities and hence exchange values is that they are objectified labor. . . [T] he only thing distinct from objectified labor is non-objectified labor, labor which is still objectifying itself, labor as subjectivity.

(Marx, Grundrisse, 271-2, qtd. in Negri, Marx Beyond Marx, 66)

We are presented with a highly ambivalent-(in the sense of a double valence or power)-condition. On the one hand, the scene bears out Agamben's argument as 'constituting power' in Fuente Ovejuna will continue to operate in relation to sovereignty-even if this relation is precisely one of its absence. At the same time, the play confirms Negri's position, too, in that constituting power releases itself here-if only during a kind of interim term-from absolute power: "de mí se vale / hasta ver si acaso sale / Comendador que la herede." "Hasta ver." We must wait and see what follows.

While he argues that "a political theory freed from the aporias of sovereignty remains unthinkable" (Homo Sacer 44), Agamben nevertheless recognizes the strength of Negri's argument for a "constituting power" independent of sovereignty, in that this would "open the way for a new articulation of the relation between potentiality and actuality" (Homo Sacer 44). It is precisely this "new ontology" that we are attempting to investigate by considering the possibility of new political relations between actuality and potentiality. Much depends on how one thinks "potentiality."

\footnotetext{
${ }^{4}$ valer (with prep. de): recurrir al favor o interposición de otro para un intento.

5 "Although the crime was grave, / since the event cannot be found out (resolved)

in writing, it must be pardoned. / It is best that the village remain / in me, since the town gets favor (protection) from me, / until it can be seen if there appears perhaps another Commander to inherit it." (My translation.)
} 
As well as on how one thinks new poetic relations. Our attempt is to read a particular paradigm-Aristotle's concept of energeia and Spinoza's concept of the body-in Fuente Ovejuna. Laurencia, who has been violated by the Commander, goes before the people of Fuente Ovejuna, with her hair disheveled, and asks: "Doesn't my hair tell its own story? Don't you see the blood on my skirt? Don't you see the bruises / Where they clutched me?/ Where they hit me? / Don't you see anything at all?' She asks for imagination, for her people's capacity to perceive her as having been objectified-(violated)-and to transform this perception into an understanding of her continuing to be violable-to which they can then oppose their collective action. Imagination, in its link to the body, here, is the main concept which leads us to a new understanding of the subject.

Through the reception of Aristotle's Poetics in Renaissance Italy and Spain, we can see how the status given the imagination in the Poetics meets what we will later find in Spinoza as the affirmative role of the imagination in the constitution of knowledge. ${ }^{6}$ In the reception of Aristotle's Poetics, we find the "first authoritative recognition" that in literature the "departure from truth [is] its essential element ... [and that] the poet's task consists of lying. . . [L]ies have a natural pleasure for man" (Forcione 22).

Spinoza's concept of imagination and its constitutive role for knowledge is clearly stated by Paolo Cristofolini: "Imagination is the capacity to make present things which could also not be." "[I]n Spinoza imagination follows all the vicissitudes of the affects; and with the affects of joy and desire, it goes from a state of passivity into one of activity, under determined conditions." 8 The "force of this reading is that instead of making imagination guilty for the dangerous relationships it can entertain with the body, it conceives of the body as a "force for the imagination itself'"(Fadini-Pascucci 12). We can now see how in Spinoza the imagination is strictly related to the body.

The body, in turn, is composed of many individuals. I quote from the Ethics II, postulates I and IV:

Postulate I: The human body is composed of very many individual parts of different natures, each of which is extremely complex. ...

Postulate IV. The human body needs for its preservation a great many other bodies, by which. . .it is continually regenerated" (Ethics II, Postulates). (76)

\footnotetext{
${ }^{6}$ By this I mean the 'optimism of reason' as reason's third stage in the constitution of knowledge (beatitudo).

${ }^{7}$ The quotation continues: "Imagination is the capacity to make present things which could also not be, in the sense of expressing in representation the idea of change which comes out of the encounter/dis-encounter of the thing with the body. Thus the capacity of representation goes together with the knowledge of what composes the encounter/disencounter with the external thing and also as non-knowledge of the essence of it- external thing. The imagination's potentia is an un-endless/inexhaustible source of communication, and it makes psychical life fluid" (Fadini-Pascucci, Immagine-Desiderio, 12).

8 "We see joy and desire expressed in the passage: 'Beyond Joy and Cupidity which are passions, there are other affects of Joy and Cupidity which refer to us as active' ( $E$ III58). This passage can be also examined from the point of view of the imagination, in its fusing itself with these active affectivities" (Cristofolini's La scienza intuitiva di Spinoza quot. in Fadini-Pascucci, Immagine-Desiderio, 11-12).
} 


\section{And the scholium to Ethics II pXVII':}

[T] he affections of the human body whose ideas set forth external bodies as if they were present to us we shall call images (imagines), although they do not reproduce the shape of things. And when the mind regards bodies in this way, we shall say that it 'imagines' (imaginari)" (Ethics II, Postulates. $)^{10}$. (78)

Now, as the individual is composed of many bodies, and since images are affects of the body, we see how the imagination can become a source of community. The affects indicate movement, and translate themselves into images-they become pictures. ${ }^{11}$

Movement is also a component of the definition of dunamis ${ }^{12}$ in Aristotle's Book Theta of the Metaphysics:

[I]t is evident that actuality is prior to potentiality. And I mean prior not only to the definite power which is said to be the source of change in something else or in some other aspect of the same thing, but to any source of motion or of rest generally. . . The logical priority of actuality, then, is clear. For what is potential in the primary sense is potential because it can become actual: what has the capacity to build means what can build; what has the capacity to see means what can see; and what is visible means what can be seen. ${ }^{13}$ (Metaphysics, Theta, 1049b1-10).

If we compare this to the passage 55a22 in the Poetics, where Aristotle writes: "[It] is necessary that the author ... should bring the play before his own eyes . . . as if he were actually present when the events happened ...," we discover that the term he uses for "actually present' is "an enargestata" (in footnote: for "energestata"), the things which are in energeia. So what has no reality yet, the possible, ${ }^{14}$ becomes actual and acquires presence through imagination. ${ }^{15}$ Here the poet's task discloses itself in all its force: he opens up an entire world unknown to reality itself, that of possible things (the dunata), changed by other things than themselves, which can come to be, or not, but which speak of the "knowledge

\footnotetext{
9 "If the human body is affected in a way (mode) that involves the nature of some external body, the human mind will regard that same external body as actually existing, or as present to itself, until the human body undergoes a further modification which excludes the existence or presence of the said body" (Spinoza, Ethics IIPXVII).

${ }^{10}$ Spinoza continues ". . . the mind does not err from the fact that it imagines, but only in so far as it is considered to lack the idea which excludes the existence of those things which it imagines to be present to itself. For if the mind, in imagining non-existing things to be present to it, knew at the same time that those things did not exist in fact, it would surely impute this power of imagining not to the defect but to the strength of its own nature, especially if this faculty of imagining were to depend solely on its own nature; that is if this faculty of imagining were free" ( $E$ I def.7). Imagination can render free.

${ }^{11}$ All these movements and reactions of our body to the impulses of the external world translate themselves into the form of impressions, affections of the body, or, in one word, images. As the mind is the idea of the body, so the images, with which the external things present themselves to us, are the ideas of the movements which happen in our body under the impulse of external causes" (Cristofolini quoted in Immagine-Desiderio, 12).

${ }^{12}$ Michelet in 1836 defines dynamis, puissance as such: "Puissance est: 1, le principe du mouvement ou du changement residant dans une autre chose, en tant qu'elle est une autre. C'est le sens propre. . . La puissance est: 2 , la faculte`d'etre change`et mis en mouvement par une autre chose, en tant qu'elle est une autre." Examen Critique de l'ouvrage d'Aristote intitule' Metaphysique.

${ }^{13}$ The passage continues: "And the same reasoning applies to other cases; so that the reason [90] or knowledge [181] of the actual must be present before [82g] there is knowledge of the potential" (Metaphysics).

${ }^{14}$ Given the possible as what can be or not be, necessarily true or possibly real, and the impossible (adunata) as what its opposite cannot not mean necessarily true (Michelet). The adunaton is affected by not-being.

${ }^{15}$ This is what we mean by 'labor.'
} 
of the potential." In the terms that concern our present worries, they speak of the labor of the reality to come. This is what Fuente Ovejuna, many in one collective body, did.

As Derrida and others have taught us, the question of the subject- "Who's there? (as Hamlet famously opens) -is, first of all, a question of language" (Keenan 13). "¿Sabe el Maestre que estoy en la villa? ... ¿ ¿sabe que soy Fernán Gómez Guzmán?" Fuente Ovejuna begins with the question of whether the Commander's presence has been recognized, a question which recurs repeatedly throughout the text. ${ }^{16}$ As the thematics of sovereignty and recognition are so much at its center, the play rather naturally lends itself to readings-(like this one)-which focus on the construction of the subject. Anthony Cascardi connects the comedia's outcome-in which the villagers do not ask to rule themselves but on the contrary desire to be re-inscribed into a relationship of service to the sovereigns (only this time the right ones) - to the history of Spain's resistance to modernization. Cascardi argues that the comedia form was one of the "imaginary mechanisms through which Spanish society resisted social transformation," and that it illustrates what Foucault describes as the subjects' "desire to seek their own domination" (Cascardi 3, 46).

While Cascardi's account includes all of the necessary terms-'imaginary mechanism,' 'subjection,' 'resistance,' and 'transformative work,'-it places them in a mistaken configuration. For it is in its resistance to-and not its complicity with-absolute power, that the 'transformative work' of the imagination is best understood in Fuente Ovejuna. If the notion of sovereignty can be understood, as we believe it can, as that which structures the hegemonic reading of an image, then Lope's play shows us the liberating side of a reading that is powered by the collective imagination.

Perhaps we see this most clearly in action in Laurencia's climactic speech. After having been raped by the Commander, she staggers into the sala del Consejo de Fuente Ovejuna and demands: “Conocéisme?" "Do you know me?" Again, the question of recognition. But now the village fathers, including her own father, do not recognize her:

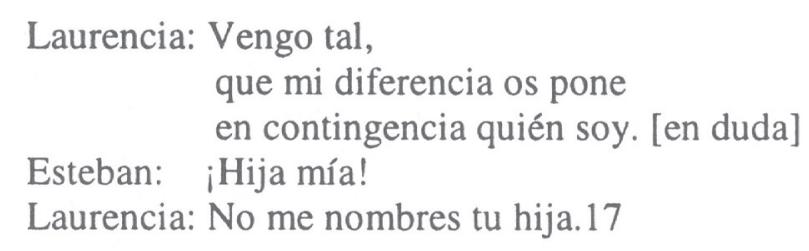

"My difference puts you_[the fathers]—in doubt of who I am." Laurencia has been changed, violated. 'Do not name me.' 'Do not call me,' she says, as she can no longer respond, no longer corresponds to the name that formerly placed her in the various orders

\footnotetext{
${ }^{16}$ In addition to opening act I, it appears again at the beginning of act II - (Cimbranos asks, “¿Está aquí el Comendador?" And Ortuño: “¿No le ves en tu presencia?" 1105-6) - and once more when he is about to be killed: "Yo estoy hablando; yo soy vuestro señor" (1886-87). By his point, however, the villagers no longer recognize him as their "lord." So that while they kill him and then mutilate his body, they invoke the names of their new lords, the "Catholic Kings," Isabel and Fernando, of whom the young Master will come to say by the end: "Son señores soberanos / y tal reconozco yo" (2149-50).

17 "I come in such state that my appearance makes you doubt who I am. / My daughter! / Don't call me your daughter." (My translation.)
} 
—familial, caste, gender - that structured her as a subject. Her-(and our)—vision of this structuring has been changed:

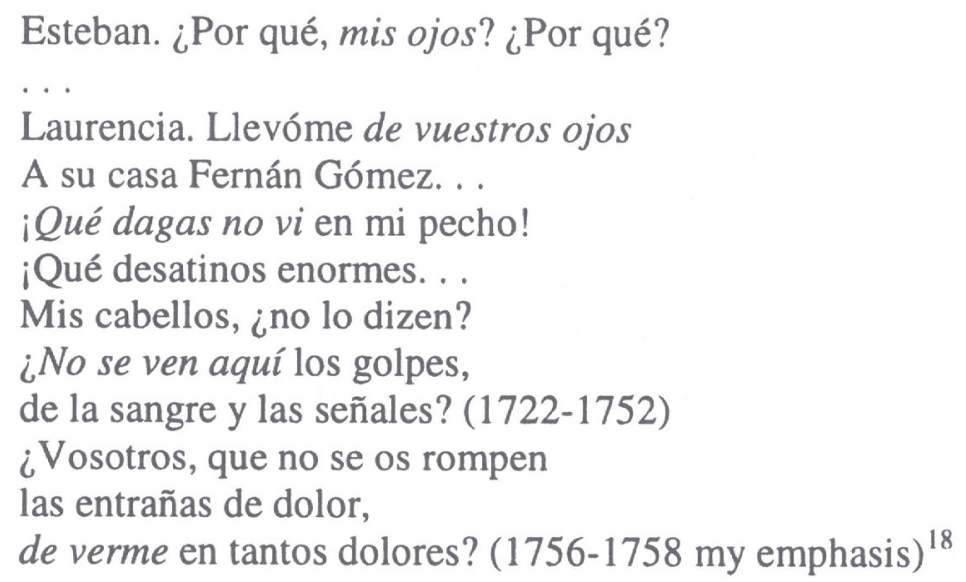

Words produce a kind of 'seeing' here which is then felt in the body, and the body, in turn, 'speaks.' Laurencia demands a reconstruction of the event based on the imaginative capacity of the villagers to 'see'- a capacity that depends on the specific labor of expressing the body as a speaking picture: "Mis cabellos, ¿no lo dizen?" The production of meaning requires her audience to 'see' as if we/they had been there. Consequently, Laurencia places the village elders in the position of the Aristotelian poet, who "should put [the events] before his eyes . . . seeing them very vividly as if he were actually present at the actions [he represents] (Poetics xvii, 22-23). Laurencia's speech transforms the villagers into authors, moving them from a state of passivity to one of activity with respect to their own construction.

Her recreation of the scene of violation through a kind of ekphrasis-the creation of a visual 'image' via words-produces that powerful [bodily] reaction that leads to what we are calling the "situation of suspension" at the end of the play, in which constituting power-agency-releases itself, if only momentarily, from sovereignty.

If we follow Spinoza here, the essential role of imagination as productive and constructive human power has already been theorized for us. The reading of the signs of her violation, which come in the form of an image, produces an emotional response-understood in terms of a Spinozian affect-an increase in the body's power of activity ( $E$ III def. 3). "[T]he affections of the human body whose ideas set forth external bodies as if they were present to us we shall call images (imagines)" (78). Specifically, this 'seeing' is what produces the affect that will bind the new community of Fuente Ovejuna.

\footnotetext{
18 "Why?, my eyes, Why? / . . Fernán Gómez took me from before your eyes to his house. What daggers didn't I see in my chest! / What enormous insanity! My hair, doesn't it tell it? / Can't you see here the blood and bruises from the blows?. . And you, aren't your insides / torn apart from the pain of seeing me in such pain?" (My translation.)
} 
After killing the commander, the villagers prepare for their trial at the hands of the Catholic Kings:

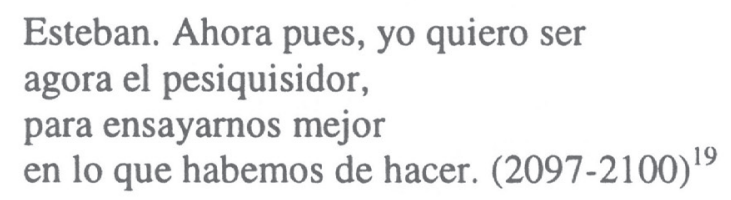

In a scene which we 'see,' the villagers play-act their torture in order to prepare for their resistance to the judge's questioning. Later, (in a scene which we do not see but which is reported) they are 'really' tortured offstage. Their rehearsal collapses the double stage between spectacle and life. Mimesis is actualized in the spectator's bodies-again, in the Spinozian sense of the movement produced by an 'affect.' Three hundred tortured bodies refuse to speak a name other than the collective village name, as the pueblo takes control of the scene of interpellation. This is the power of energeia. As they move from a position of passivity to one of activity via their own theatrical anticipation of their torture, they ultimately create a new status of being. Again, what we are emphasizing is that this resistance to law's attempt to write a verdict on their bodies works via an imaginary act, through a collective praxis which transforms them from the object into the collective subject of politics. $^{20}$

What is the relationship between the founding of the community and this collective selfauthorship? In place of the written evidence needed to find out what happened, which has proven to be unproducible, the villagers offer their own bodies as a kind of alternative writing-one which is, juridically speaking, unreadable. Resistance takes the form of a bodily 'poetics': the desire to determine the historicity of the event cannot overcome this poetic construction, which effectively steps in for history. ${ }^{21}$

The connection between energeia and the construction of the subject as the result of desire (Spinozian affect) centers on the question of agency. Lope's play presents a postmodern concept of the subject in the sense that, as Deleuze writes, "[t]here is no longer $a$ subject, but only individuating affective states of an anonymous force" (Spinoza's Practical Philosophy, 128). This takes us back to the questions of agency with which we began. Opposed to the Enlightenment view of the subject and politics as calculable, we propose for re-consideration today Lope's representation of a collective subject figured in terms of its productive capacity.

Finally, since we began with a quote from Negri, we will close with one last one, but this time in the form of a question. Negri asks: "How can freedom from below be related to absoluteness?" The answer he offers is that Democracy will appear as "constituent power" (Dionysus 311). "When the subjects have become autonomous producers of wealth, knowl-

\footnotetext{
19 "Now then, I now want to be the questioner / in order to better rehearse / what we need to do."

${ }^{20}$ It is precisely this move from object to subject that marks, for Agamben, the "birth of democracy" (Homo Sacer 9).

${ }^{21}$ See Aristotle's Poetics: "[I]t is the function of the poet to relate not things that have happened but things that may happen. . . . For this reason poetry is more philosophical and more serious than history. . . The reason is that what is possible is believable. .." (viii 51b5ff. Janko translation, 12).
} 
edge and cooperation, without the need of external command, when they organize production itself and social reproduction, there is no reason for an overarching sovereign power external to their own power" (Dionysus 312). In the Political Tractatus, Spinoza writes, "For absolute sovereignty, if any such thing exists, is really the sovereignty held by a whole people." (PT, VIII, 3) $)^{22}$

Is this conception of sovereignty as "absolutum imperium," as Spinoza calls it, ${ }^{23}$ utopic? Is it a dream? Perhaps. For now it remains for us, like the 'hasta ver,' an open question. Yet if this conception of the power of the subject was already on the threshold in the seventeenth century, now in our 'postmodernity,' we see our task as the effort to realize itthrough our own collective and productive labor.

\section{WORKS CITED}

Agamben, Giorgio. Homo Sacer. Trans. Daniel Heller-Roazen. Stanford: Stanford UP, 1998.

Aristotle. Poetics. Trans. Richard Janko. Indianapolis: Hackett, 1987.

Metaphysics. Books I-IX. Edited by G.P. Goold. Trans. Hugh Tredennick. Cambridge: Harvard UP, 1997.

Balibar, Etienne. Spinoza and Politics. Trans. Peter Snowdon. London: Verso, 1998.

Cascardi, Anthony J. Ideologies of History in the Spanish Golden Age. University Park: Pennsylvania State UP, 1997.

Deleuze, Gilles. Expressionism in Philosophy: Spinoza. Trans. Martin Joughin. New York: Zone Books, 1990.

—. Spinoza: Practical Philosophy. Trans. Robert Hurley. San Francisco: City Lights Books, 1988.

Anti-Oedipus_Capitalism and Schizophrenia. Trans. Robert Hurley, Mark Seem, Helen R. Lane. Preface by Michel Foucault. Minneapolis: U of Minnesota P, 1986.

\footnotetext{
${ }^{22}$ And in his conclusion to his book on Spinoza, Etienne Balibar supports this reading: "The individual is neither created by God according to an eternal model nor delivered by nature as a kind of raw material. The individual is a construction. This construction is the result of a striving (conatus) by the individual himself, within the determinate conditions of his "way of life." And that "way of life" is nothing other than a given regime of Communication (affective, economic or intellectual) with other individuals. The different regimes of communication form a sequence through which a collective effort is being worked out - the effort to transform the mode of communication, to move from relationships of identification (that is, from the mode of communion) to relationships based on exchange of goods and knowledge. The political state itself is essentially one such regime. But Spinoza's definition of the State, although still rigorously realistic, is clearly also much broader than the juridical and administrative form that is referred to by that name in the modern period (that is, the period of the bourgeois nation-state). Thus, this definition can help us to envisage, at least in theory, historical forms of the State other than the present form. And it also identifies for us the decisive mechanism by which those new forms can be created: the democratisation of knowledge." Spinoza and Politics. Verso: London: 1998. 124.

${ }^{23}$ Tractatus Politicus, chap. XI, 1 in Spinoza The Political Works, ed. A.G. Wernham. Oxford: Clarendon Press, 1958, 440.
} 
Fadini, Ubaldo and Giammario Pascucci. Immagine-Desiderio-Contributo ad una genealogia del moderno. Milano: Associazione Culturale Mimesis, 1999.

Forcione, Alban, K. Cervantes, Aristotle, and the Persiles. Princeton: PUP, 1970.

Keenan, Thomas. Fables of Responsibility-Aberrations and Predicaments in Ethics and Politics. Stanford: SUP, 1997.

Marx, Karl. Grundrisse. Trans. Martin Nicolaus. London: Penguin Books, 1993.

Montag, Warren \& Ted Stolze, eds. The New Spinoza. Theory Out of Bounds. Vol. 11. Minneapolis: U of Minnesota P, 1997.

Negri, Antonio. The Savage Anomaly-The Power of Spinoza's Metaphysics and Politics. Trans. Michael Hardt. Minneapolis: U of Minnesota P, 1991.

- Labor of Dionysus. Theory Out of Bounds. Vol. 4. Eds. Buckley, Massumi, Hardt. Minneapolis: U of Minnesota P, 1994.

- Marx Beyond Marx-Lessons on the Grundrisse. Trans. H. Cleaver. Boston: Bergin \&Garvey, 1984. 66-71.

Spinoza, Benedict de. The Ethics. Treatise on the Emendation of the Intellect. Selected Letters. Trans. Samuel Shirley. $2^{\text {nd }}$ Edition. Edited with Introduction by Seymour Feldman. Indianapolis: Hackett, 1992.

- The Political Works. Ed. A.G. Wernham. Oxford: OUP, 1958.

Vega Carpio, Lope Félix de. Fuente Ovejuna. Decimonovena edición. Ed. Rinaldo Froldi. Madrid: Espasa Calpe, S.A., 1998. 